\title{
Digital Academic Education during Covid-19 Pandemic - Perception of College and School students in Andhra Pradesh
}

\author{
Kutty Kumar \\ Sri Venkateswara Veterinary University \\ College of Veterinary Science \\ Library and Information Science, Andhra Pradesh, India \\ kumarkkutty@gmail.com
}

\begin{abstract}
The purpose of this study is to examine the view of college and school students of Andhra Pradesh on virtual education through web conference tools in response to the Covid-19 crisis. From July to September 2020, an online survey was conducted, with 123 responses selected for the study. For answering the study objectives, the data was examined using the Mann Whitney $\mathrm{U}$ test and the Friedman test. Out of 123 people who took part in the online survey, 48\% were high school students and $52 \%$ were college students, male respondents made up $63 \%$ of the overall population while female respondents made up $37 \%$. The majority of school pupils (30\%) were aged 12 to 15, while the majority of college students (39\%) were aged 20 to 23 . When it came to accessing web-conference applications, the most popular choices among survey participants were Mobile and Tablet. The most often utilized web conferencing tools for virtual learning were Zoom (90\%) and Cisco Webex Meeting (87\%). The results of the Mann Whitney $U$ test revealed that college students scored higher than schoolchildren, implying that the former population was more responsive to certain aspects of online education than the latter. The test revealed a statistically significant discrepancy between college and school students' expectations of the benefits and drawbacks of online learning. Furthermore, the Friedman test revealed a significant difference in total satisfaction between college and school students ( $\chi 2$ ( 1 ) $=29.121, p \leq 0.000$ ). Additionally, both the school and college populations benefited from online library services such as virtual book exhibitions, webinars, and awareness programmes on Covid-19 and academic/research-related topics; lowering penalty/ overdue charges on borrowed library materials; providing licenced electronic resources and educational video materials.
\end{abstract}

Keywords: online education, Covid-19 lockdown, web conference tools, school, college students, U-test, online library services

\section{Introduction}

Covid-19 has gripped the world at a time when many things are changing and forcing paradigm transformations. It has compelled us to reconsider the traditional educational model and challenge how it is delivered. The coronavirus, according to many investigations and warnings from the World Health Organization, may be here to stay. While the number of Covid-19 positives may vary significantly around the globe, school interferences due to the pandemic are currently affecting too much. ${ }^{1}$ Some are wondering if online learning will continue post-pandemic, and how such a move may affect the global education scenario, given the abrupt shift away from the classroom in many regions of the world. Educators have played a critical role in developing online and offline learning technologies to ensure that school and college students continue to learn in light of the current circumstances. 
Kumar K. "Digital Academic Education during Covid-19 Pandemic - Perception of College and School students in Andhra Pradesh", $3-24$

In response to tremendous demand, there are numerous platforms for online learning available, such as BYJU'S, Bangalore-based learning expertise and online tutoring firm founded in 2011, are providing free access to their services. ${ }^{2}$ BYJU saw a $200 \%$ increase in new students using its Think and Learn app after introducing free live sessions. ${ }^{3}$ Temporarily, Wuhan, China Tencent Classroom has been in broad practice since the Chinese government ordered a quarter of a billion full-time students to restart their education on online platforms in mid-February 2020. With over $81 \%$ of $\mathrm{K}-12$ pupils taking classes online, the biggest "online movement" in educational history has occurred. ${ }^{4}$ Others are expanding their capacity to serve instructors and students as a one-stop shop. For instance, to ensure reliable communication during the Covid-19 crisis, Lark, a Singapore based firm improved its worldwide server architecture and technological skills. ${ }^{5}$ In the USA, school districts are developing one-of-a-kind collaboration, such as the partnership between the Los Angeles Unified School District and PBS SoCal/KCET to provide local educational broadcasts with dedicated channels for different age groups and a range of digital options. ${ }^{6}$ However, there are obstacles to overcome. Students cannot utilize the internet since they do not have reliable internet connectivity or equipment, some have difficulty participating in digital learning; this imbalance exists between countries and within countries at different socioeconomic levels. Allowing to the poll, in Switzerland, Norway, and Austria, 95\%of students have access to a workstation for instruction. Whereas only $34 \%$ of children in Indonesia have it. ${ }^{7}$ Further, there is a considerable disparity between those from wealthy and poor homes in the United States: although virtually all wealthy 15 -year-olds stated they had access to a computer, nearly $25 \%$ of those from low-income families indicated they are not prepared. While certain schools and governments, like those in New South Wales, Australia, have provided pupils in need with digital devices, many others are concerned that the pandemic would exacerbate the digital divide. $^{8}$

In India, the Coronavirus pandemic and subsequent lockdown have prompted educational institutions across the country to temporarily close, resulting in a large gap in the education system because of this unanticipated turn of events. Both the central and state governments to maintain online education have adopted several measures. The Government of India has introduced multiple "PM e-Vidya", "Bharat Padhe", and "Vidya Daan 2.0" stimulus programs to expand the country's e-learning prospects. Furthermore, initiatives such as the Diksha site (e-pathshala), Swayam Prabha, and the NCERT (National Council of Educational Research and Training) YouTube channels encouraging e-content for students of various grades. ${ }^{9}$ Now, in the wake of the Covid-19 pandemic, video conferencing software has emerged as a critical tool for

\footnotetext{
2 Shivangi Dhawan, "Online Learning: A Panacea in the Time of COVID-19 Crisis", Journal of Educational Technology Systems 49, 1 (2020): 5-22, https://doi.org/10.1177/0047239520934018.

3 Sasikanta Tripathy and Suman Devarapalli, "Emerging Trend Set by a Start-ups on Indian Online Education System: A Case of Byju's", Journal of Public Affairs 21, 1 (2021), https://doi.org/10.1002/pa.2128.

${ }^{4} \mathrm{H}$. Wiranota and T. T. Wijaya, "The International Students' Perception towards Online Learning Using the Tencent Meeting during Covid-19 Outbreak", Journal of Physics: Conference Series 1823, 1 (2021): 012011, https://doi.org/10.1088/1742-6596/1823/1/012011.

5 Austin Mardon, Catherine Mardon and Jiahui Mardon Luo, Education During COVID-19 (S. I.: Golden Meteorite Press, 2020).

${ }^{6}$ Yanbin Xu and Zhekai Wu, "An Investigation of Obstacles of Current Online Classes Encountered by Students from an International Department of a Senior High School in Hangzhou during the 2019-NCov Period", in Proceedings of the $20203 \mathrm{rd}$ International Conference on Humanities Education and Social Sciences (ICHESS 2020) (Chengdu, China: Atlantis Press, 2020), https:// doi.org/10.2991/assehr.k.201214.486

7 OECD, "Learning Remotely When Schools Close: How Well Are Students and Schools Prepared? Insights from PISA", OECD Policy Responses to Coronavirus (COVID-19), 2020, https://doi.org/10.1787/3bfda1f7-en.

8 OECD, Education Responses to COVID-19: Embracing Digital Learning and Online Collaboration, March 2020, https://read.oecd-ilibrary. org/view/?ref=120_120544-8ksud7oaj2\&title=Education_responses_to_Covid-19_Embracing_digital_learning_and_online_ collaboration\&_ga=2.196555183.2030078247.1626438563-540793052.1625722470.

9 Sarif Nawaz, "Revisiting the Discourse on Online and Face-to-Face Classes amidst Covid-19 Lockdown: Digital Outreach, StrengthWeakness Analysis, and Constructivist View", South Asia Journal (blog), June $7^{\text {th }}, 2020$, http://southasiajournal.net/revisiting the-discourse-on-online-and-face-to-face-classes-amidst-covid-19-lockdown-digital-outreach-strength-weakness-analysis-andconstructivist-view/.
} 
Kumar K. "Digital Academic Education during Covid-19 Pandemic - Perception of College and School students in Andhra Pradesh", $3-24$

keeping people linked and bridging distance education. The use of a virtual classroom has revolutionized the teaching and learning practice if class and care inequities are no lengthier an issue. Hundreds of students can simply attend a lecture session without any hindrance. ${ }^{10}$ Several colleges across the country are now offering online courses to let students continue their education from the convenience of their own homes. Several research used technology to address the positive aspects of Covid-19 and the improvement of perceptual functioning by involving students in various interactive sessions. ${ }^{11}$

At this juncture, the government of Andhra Pradesh (AP) has turned to channels to provide education. Officials in the state of Andhra Pradesh have been urged to enrol in online courses. The State has been conducting virtual classrooms using Skype, Cisco, Teamlink, Google Meet, and Microsoft Teams to guarantee that academic activities continue. Over 24,000 students and 933 professors are enrolled in online classrooms during the lockdown, according to a statement made by the AP state government. ${ }^{12}$ According to the statement, for individuals who do not have access to the internet, lectures on several subjects are published on YouTube and the links are shared with students so that they can benefit. For the convenience of students, lecture summaries are also shared via WhatsApp and e-mail. Currently, 5979 classes are being held in various disciplines such as $B$. Tech, $M$. Tech, BA, MA, MCA, MBA, and others. To keep the curriculum balanced, educational institutions are also working to finish pending syllabuses and engage students effectively throughout the lockdown. Tenth-grade students can also participate in Doordarshan lessons, which are broadcast twice a day, in the morning and evening. Every day, there is also a radio broadcast. The state government has also developed an app for online classes, such as Abhyasa, a self-learning app with tenth-grade subject videos sourced from Dhiksha and objective style question questions. Every school will have a WhatsApp group with teachers and tenth-grade pupils, according to the government norms. ${ }^{13}$ During the Covid-19 pandemic, the current study aimed to classify the attitudes of Andhra Pradesh School and college students about online learning, where remote learning has arisen as the only choice for learning. Further, the study intended to understand how libraries are adapting and how their function is changing to meet community needs.

\section{Review of Literature}

Khalil et al. ${ }^{14}$ carried out a qualitative study by synchronous virtual focus group debates with the help of a discussion guide comprised of seven open-ended questions. Using a maximum sampling technique for variation, 60 medical students were recruited, who later participated in eight discussions in the focus group. The findings revealed that the online mode was well welcomed,

10 Edeh Michael Onyema et al., "Impact of Coronavirus Pandemic on Education", Journal of Education and Practice (May 2020), https:// doi.org/10.7176/JEP/11-13-12

11 Veena Shenoy, Sheetal Mahendra and Navita Vijay, "COVID 19 - Lockdown: Technology Adaption, Teaching, Learning, Students Engagement and Faculty Experience", Mukt Shabd Journal IX, IV (2020): 698-702; Radha, R. et al.. "E-Learning during Lockdown of Covid-19 Pandemic: A Global Perspective", International Journal of Control and Automation 13, 4 (2020): 1088-1099; David Mhlanga and Tankiso Moloi, "COVID-19 and the Digital Transformation of Education: What Are We Learning on 4IR in South Africa?", Education Sciences 10, 7 (2020): 180, https://doi.org/10.3390/educsci10070180; Padmini G. Devi and Sirisha Deepthi Sornapudi, "An Insight into Digital Education in India during COVID-19 from the Lens of Students", Current Journal of Applied Science and Technology (November 2020): 83-94, https://doi.org/10.9734/cjast/2020/v39i3531057.

12 "AP Government Uses Online Platforms Educate Students during Covid-19 Lockdown - Education Today News", India Today, May $11^{\text {th }}, 2020$, https://www.indiatoday.in/education-today/news/story/ap-goverment-uses-online-platfroms-educate-studentsduring-covid-19-lockdown-1676707-2020-05-11.

13 Department of School Education \& Literacy, Ministry of Human Resource Development, and Government of India, "India Report Digital Education" (New Delhi, 2020), file:///C:/Users/Nanchari/Desktop/CAEO\%20Reviewer/India_Report_Digital_Education_0.pdf.

14 Rehana Khalil et al., "The Sudden Transition to Synchronized Online Learning during the COVID-19 Pandemic in Saudi Arabia: A Qualitative Study Exploring Medical Students' Perspectives", BMC Medical Education 20, (2020), https://doi.org/10.1186/ s12909-020-02208-z. 
Kumar K. "Digital Academic Education during Covid-19 Pandemic - Perception of College and School students in Andhra Pradesh", $3-24$

with all participants agreeing that online sessions saved them time and improved their performance, resulting in time used excessively; but they suggested that during sessions and online tests they encountered some difficulties, including procedural, content comprehension, technological and undesirable behaviours. For the following academic years, most preclinical students preferred online learning. Another study ${ }^{15}$ examined the understanding of teachers and students of online education in a related analysis of its benefits, disadvantages, and recommendations. The results listed virtual learning, convenience, accessibility as advantages; the drawbacks were related to inefficiency and difficulty in maintaining intellectual integrity. The study promoted the use of online learning in medical and dental institutions, taking into account its many advantages that enabled student-centred learning. Correspondingly, Rajab et al. ${ }^{16}$ also addressed the effects of the Covid-19 pandemic on online education at the Alfaisal University College of Medicine (COM) in Riyadh, Saudi Arabia. The research concluded that online education showed that the Covid-19 threat had a largely positive effect on online medical education. Subsequently, Amita ${ }^{17}$ obtained online input from students of higher education institutions about their experience with e-learning approaches used by their faculty and institute. The findings showed that the faculty did its best in this crisis period because, despite some difficulties, the software resources helped the students cover the majority of their syllabus. A global reaction made by Bozkurt et al., ${ }^{18}$ in response to the disruption of education due to the Covid-19 pandemic, narrating the overall perspective, reflections from the higher education landscape, and recommendations from a total of 31 countries worldwide. The results of this study indicate that current activities are defined as remote emergency education and that this activity varies from methods such as distance learning, online learning, or other derivatives that are expected. The study addressed how social disparity, racism, and the digital divide stepped up during the pandemic.

\section{Objectives}

- To ascertain the views of students during the Covid-19 threat about online education;

- To find the disparity between the understanding of the merits and drawbacks of online digital education between school students and college students.

\section{Hypothesis}

$\mathrm{H} 1$ : There is no major difference between the real-time experience of college and school learners with online education in the course of the Covid-19 pandemic.

$\mathrm{H} 2$ : A major gap existed between the real-time experience of college and school students with education online during the pandemic of Covid- 19 .

H3: In response to the Covid-19 lockdown, there is no substantial difference between college and school students in overall satisfaction with the online education experience.

$\mathrm{H} 4$ : There is a wide disparity in overall satisfaction between college and school students concerning the experience of online education in response to the Covid-19 government shutdown.

\footnotetext{
15 Khadijah Mukhtar et al., "Advantages, Limitations and Recommendations for Online Learning during COVID-19 Pandemic Era", Pakistan Journal of Medical Sciences 36 (COVID19-S4) (2020), https://doi.org/10.12669/pjms.36.COVID19-S4.2785.

16 Mohammad H. Rajab, Abdalla M. Gazal and Khaled Alkattan, "Challenges to Online Medical Education During the COVID-19 Pandemic", Cureus, July 2020, https://doi.org/10.7759/cureus.8966.

17 Amita, E-Learning Experience of Students in Higher Education Institutions During the COVID-19 Pandemic: A Primary Survey. COVID-19 Pandemic: A Global Challenge (New Delhi: Raj Pal Singh, Anupama Singh and Rakesh Kumar; COVID-19 Pandemic: A Global Challenge, Aryan Publications, 2020).

18 Aras Bozkurt et al., "A Global Outlook to the Interruption of Education Due to COVID-19 Pandemic: Navigating in a Time of Uncertainty and Crisis", Asian Journal of Distance Education 15, 1 (2020): 1-126.
} 


\section{Assumptions}

1. Data from students attending online learning due to the pandemic of Covid-19 was obtained and expressed their commitment to engage in the study.

2. Study participants, regardless of their familiarity using it, were aware of online education through video conferencing resources.

3. Research participants replied truthfully to all aspects of the research questions.

\section{Methodology}

The data was collected through a self-administered, structured questionnaire that was circulated online through student forum, what's app group, and e-mail, which drew 123 responses from Andhra Pradesh state, India during the period July 2020 to September 2020. The respondents included school students who were doing their $9^{\text {th }}, 10^{\text {th }}, 11^{\text {th }}$, and $12^{\text {th }}$ grade and college students, doing their undergraduate and postgraduate courses in various disciplines. The questionnaire was mailed to parents' e-mail for those respondents who did not have their email account. The questionnaire ${ }^{19}$ is divided into 3 sections. Section 1 focused on demographic information that included age, educational status, electronic gadgets preferred for attending online classes, and web conference applications used by their respective institutions. Section 2 pondered the positive and negative dimensions of the interactive learning software and the general happiness of students using the "Excellent (1), Good (2), Average (3), Poor (4)" 4-point Likert scale. Section 3 had questions related to online library services during pandemic. The research findings provided using the Mann-Whitney $U$ measure. The variations between two distinct groups on a continuous scale are investigated by the statistical methodology, therefore a particular statistical technique that varies greatly from other nonparametric tests is called a specific statistical technique. ${ }^{20}$ Friedman Test was used to interpret the overall satisfaction of respondents for online learning experienced by them during this lockdown. Assumptions to ensure whether the Mann-Whitney $\mathrm{U}$ test data is accurate. ${ }^{21}$

In this analysis, the perception of respondents towards different features of online education using web conference resources during the Covid-19 disaster is the dependent variable, calculated on an ordinal scale and the grouping variable is students' perception of different features of online education during the Covid-19 crisis. Simply put, in the middle of a pandemic (dependent variable), we want to know how good or bad school and college students (independent variable) feel about online education.

1. "Two independent, categorical groups should be the independent variable" - here, the explanatory variables refer to responses from school and college students about practical merits and downsides of online education they encounter during the Covid-19 lockdown.

2. "Observations should be autonomous". There is no association between the two classes here. (College and school).

3. "Observations are not usually distributed". Nevertheless, those ${ }^{22}$ should adopt the same form (i.e. both are bell-shaped and left-skewed).

\footnotetext{
19 The Questionnaire is available at https://forms.gle/N3Mgf1bcYaQELUqr9.

20 Živorad Milenović, "Application of Mann-Whitney U Test in Research of Professional Training of Primary School Teachers", Metodički Obzori / Methodological Horizons 6, 1 (2011): 73-79, https://doi.org/10.32728/mo.06.1.2011.06; Jennifer K. Peat et al., Health Science Research: A Handbook of Quantitative Methods (2020), https://www.taylorfrancis.com/books/9781003115922.

${ }^{21}$ Stephanie, "Mann Whitney U Test: Definition, How to Run", Statistics How To, April 25th, 2021, https://www.statisticshowto.com/ mann-whitney-u-test/.

22 Justine Rochon, Matthias Gondan and Meinhard Kieser, "To Test or Not to Test: Preliminary Assessment of Normality When Comparing Two Independent Samples", BMC Medical Research Methodology 12, 1 (2012), https://doi.org/10.1186/1471-2288-12-81.
} 
Kumar K. "Digital Academic Education during Covid-19 Pandemic - Perception of College and School students in Andhra Pradesh", $3-24$

Table 1: Tests of Normality

\begin{tabular}{|c|c|c|c|c|c|c|}
\hline \multirow{3}{*}{$\begin{array}{l}\text { Rating Usefulness of } \\
\text { Web Conference Tools for } \\
\text { E-Learning }\end{array}$} & \multicolumn{3}{|c|}{ Kolmogorov-Smirnova } & \multicolumn{3}{|c|}{ Shapiro-Wilk } \\
\hline & Statistic & Df & Sig. & Statistic & df & Sig. \\
\hline & .259 & 123 & .000 & .806 & 123 & .000 \\
\hline
\end{tabular}

a. Lilliefors Significance Correction

From the normality assumption shown in Table 1, it is clear that both Kolmogorov-Smirnov and Shapiro-Wilk imply that the dependent variable is not normally distributed. Besides, to see whether information seems possible, a split histogram is done. In the figure, unusual values or patterns are not observed. Secondly, the outcome variables are not normally distributed and a total sample size of $n=123$. Finally, it could be understood from the figure that the pros and cons of online learning using web conference tools during Covid-19 lockdown are rated more favourably by school versus college respondents. In the following sections, the analysis was carried out to find whether sample differences are large enough for refuting the hypothesis.

Figure 1: Split Histogram in Education Variables

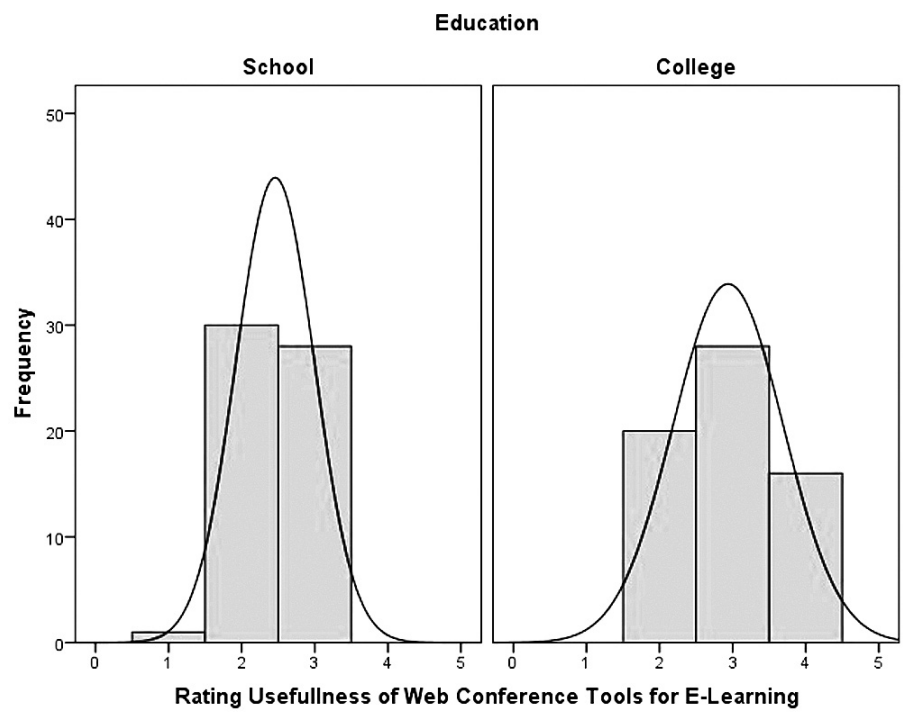

\section{Results and Discussion}

\section{Demographic data}

The demographic information of students who participated in the survey is tabulated in Table 2. Out of a total of 123 respondents, 59 belonged to school while 64 were from college accounting for $62.60 \%$ male and $37.40 \%$ female population. Unsurprisingly school students (48\%) were between the ages group 15 to 19 and most of the college students (40.65\%) were in the middle of $20-23$ years, however, $11.38 \%$ were found above 24 years of age. 
Kumar K. "Digital Academic Education during Covid-19 Pandemic - Perception of College and School students in Andhra Pradesh",

Table 2: Respondent Demographics

\begin{tabular}{|c|c|c|c|}
\hline Gender & $\begin{array}{l}\text { School } \\
59(47.97)\end{array}$ & $\begin{array}{l}\text { College } \\
64(52.03)\end{array}$ & $\begin{array}{l}\text { Total } \\
\mathrm{N}=123(100)\end{array}$ \\
\hline Male & $\begin{array}{l}40 \\
(32.52)\end{array}$ & $\begin{array}{l}37 \\
(30.08)\end{array}$ & $\begin{array}{l}77 \\
(62.60)\end{array}$ \\
\hline Female & $\begin{array}{l}19 \\
(15.45)\end{array}$ & $\begin{array}{l}27 \\
(21.95)\end{array}$ & $\begin{array}{l}46 \\
(37.40)\end{array}$ \\
\hline \multicolumn{4}{|l|}{ Age } \\
\hline $12-15$ & $\begin{array}{l}36 \\
(29.27)\end{array}$ & 0 & $\begin{array}{l}36 \\
(29.27)\end{array}$ \\
\hline $16-19$ & $\begin{array}{l}23 \\
(18.70)\end{array}$ & $\begin{array}{l}2 \\
(1.63)\end{array}$ & $\begin{array}{l}25 \\
(20.33)\end{array}$ \\
\hline $20-23$ & 0 & $\begin{array}{l}48 \\
(39.02)\end{array}$ & $\begin{array}{l}48 \\
(39.02)\end{array}$ \\
\hline Above 24 & 0 & $\begin{array}{l}14 \\
(11.38)\end{array}$ & $\begin{array}{l}14 \\
(11.38)\end{array}$ \\
\hline
\end{tabular}

(Figures in parenthesis indicate percentages)

\section{Preferred electronic gadget for attending the online class}

As reported by Muthuprasad et al. ${ }^{23}$ and Abbasi et al. ${ }^{24}$ in their study on students perception for using electronic devices for e-learning that mobile phones are mostly preferred by students, the data in figure 1 shows that mobile phones (98\%) have become one of the popular devices having chosen by $45 \%$ of school and $52 \%$ college learners for online education. Similarly, $70 \%$ of the total population preferred Tablet. On the contrary, other electronic gadgets viz laptop (41\%), desktop (16\%), and Smart Television (28\%) are least preferred by respondents.

Figure 2: Distribution of Gadgets

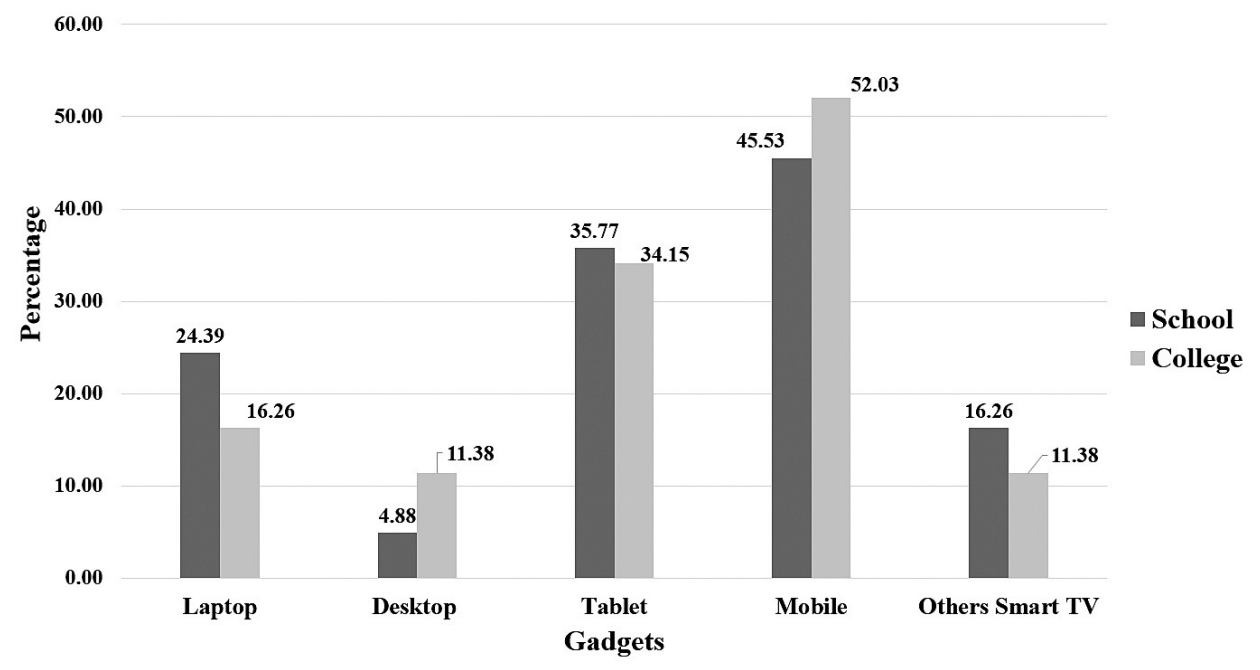

\footnotetext{
${ }^{23}$ T. Muthuprasad et al., "Students' Perception and Preference for Online Education in India during COVID-19 Pandemic", Social Sciences \& Humanities Open 3, 1 (2021): 100101, https://doi.org/10.1016/j.ssaho.2020.100101.

${ }^{24}$ Sahar Abbasi et al., "Perceptions of Students Regarding E-Learning during Covid-19 at a Private Medical College", Pakistan Journal of Medical Sciences 36 (COVID19-S4) (2020), https://doi.org/10.12669/pjms.36.COVID19-S4.2766.
} 
Kumar K. "Digital Academic Education during Covid-19 Pandemic - Perception of College and School students in Andhra Pradesh", $3-24$

\section{Web Conference Applications}

In an online course, there are many ways that web conferencing can aid. Not only does web conferencing encourage students to hear a guest speaker, but they also connect and ask questions. In addition, most of the web conference software enables to record the session easily and make it accessible for analysis or for students who were unable to make the initial time available. ${ }^{25}$ It is vivid from figure 3 that "Zoom" is the most used web application (90\%) followed by the "Cisco Webex meeting (87\%)".

Figure 3: Web conference applications

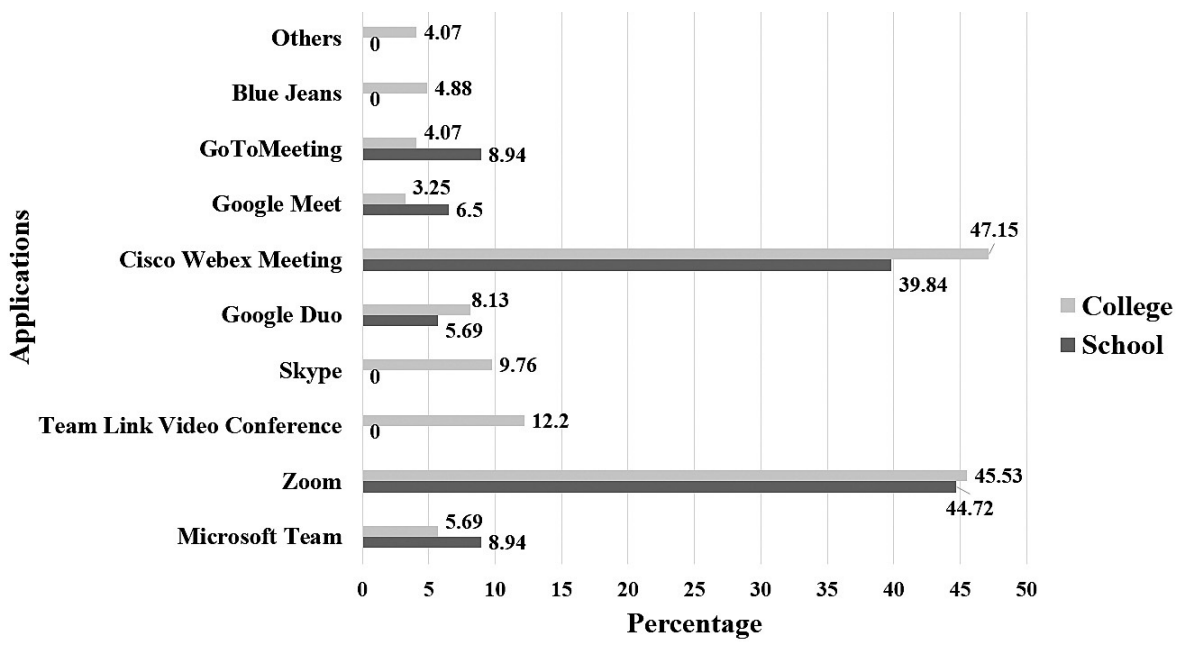

Table 3: Mean ranks of advantages and disadvantages of online learning from a student perspective

\begin{tabular}{|l|l|l|l|l|l|}
\hline S. & Advantages & $\begin{array}{l}\text { Mean Rank } \\
\text { School } \\
(\mathrm{N}=59)\end{array}$ & $\begin{array}{l}\text { Mean Rank } \\
\text { College } \\
(\mathbf{N}=64)\end{array}$ & $\begin{array}{l}\text { Sum of } \\
\text { Ranks } \\
\text { School }\end{array}$ & $\begin{array}{l}\text { Sum of } \\
\text { Ranks } \\
\text { College }\end{array}$ \\
\hline 1 & Study materials (word file/pdf, ppt) & 50.55 & 72.55 & 2982.50 & 4643.50 \\
\hline 2 & Lectures on Television (Eg Swayam Prabha) & 54.11 & 69.27 & 3192.50 & 4433.50 \\
\hline 3 & No travel and accommodation expenses & 59.71 & 64.11 & 3523.00 & 4103.00 \\
\hline 4 & Offline video lectures & 52.67 & 70.60 & 3107.50 & 4518.50 \\
\hline 5 & Self-assessment test & 51.97 & 71.25 & 3066.00 & 4560.00 \\
\hline 6 & Improves responsibility and time-management skill & 53.97 & 69.41 & 3184.00 & 4442.00 \\
\hline 7 & Promote active and Independent learning & 55.10 & 68.36 & 3251.00 & 4375.00 \\
\hline 8 & Remote learning & 61.54 & 62.42 & 3631.00 & 3995.00 \\
\hline 9 & $\begin{array}{l}\text { Over discussion board and chats, questions } \\
\text { explained promptly }\end{array}$ & 65.60 & 58.68 & 3870.50 & 3755.50 \\
\hline 10 & $\begin{array}{l}\text { Information acquisition from mobile applications } \\
\text { (such as Byjus, Vedantu, Extra points, etc) }\end{array}$ & 47.01 & 75.82 & 2773.50 & 4852.50 \\
\hline 11 & Others & 57.45 & 66.20 & 3389.50 & 4236.50 \\
\hline
\end{tabular}

\footnotetext{
${ }^{25}$ Rahul De', Neena Pandey and Abhipsa Pal, "Impact of Digital Surge during Covid-19 Pandemic: A Viewpoint on Research and Practice", International Journal of Information Management 55 (December 2020): 102171, https://doi.org/10.1016/j. ijinfomgt.2020.102171.
} 


\begin{tabular}{|c|c|c|c|c|c|}
\hline \multicolumn{6}{|c|}{ Disadvantages } \\
\hline 1 & Faculties rush the syllabus & 56.97 & 66.64 & 3361.00 & 4265.00 \\
\hline 2 & $\begin{array}{l}\text { Non-accessibility of adequate electronic devices } \\
\text { (in homes with two or more siblings) }\end{array}$ & 63.63 & 60.50 & 3754.00 & 3872.00 \\
\hline 3 & Poor internet connectivity & 59.47 & 64.34 & 3508.50 & 4117.50 \\
\hline 4 & Electricity Problem & 54.97 & 68.48 & 3243.00 & 4383.00 \\
\hline 5 & Lack of technical skills & 51.97 & 71.25 & 3066.00 & 4560.00 \\
\hline 6 & Poor video quality & 51.97 & 71.25 & 3066.00 & 4560.00 \\
\hline 7 & $\begin{array}{l}\text { Online tests are limited to multiple-choice } \\
\text { questions }\end{array}$ & 66.60 & 57.76 & 3929.50 & 3696.50 \\
\hline 8 & Difficulty in practical-based knowledge & 45.84 & 76.90 & 2704.50 & 4921.50 \\
\hline 9 & Security issues & 51.97 & 71.25 & 3066.00 & 4560.00 \\
\hline 10 & $\begin{array}{l}\text { The authenticity of the work of students (teachers } \\
\text { do not track whether a student practices the work) }\end{array}$ & 49.05 & 79.94 & 2894.00 & 4732.00 \\
\hline 11 & Too much time spent on a computer & 53.97 & 69.41 & 3184.00 & 4442.00 \\
\hline 12 & Others & 65.37 & 58.89 & 3857.00 & 3769.00 \\
\hline
\end{tabular}

The Mann Whitney test works by creating a ranked list of the findings labelled in their two classes first. It will then function from the lowest observation and send the observation rank 1 and the next rank 2 and so on to the largest observation that will have rank 123 in this case. Although ignoring the grouping variable (in this analysis, college, and school students), the test works by transforming scores into ranks and then comparing the mean rank of each group.

The test statistics (table 4) make available information regarding the productivity of the Mann-Whitney $\mathrm{U}$ test. As mentioned earlier, college students have higher ranks compared to school students suggesting that the former gave a greater response towards various features of online education amidst the Covid-19 lockdown. The table includes three test statistics $(U, W$, and Z), but it is normal to report the Mann-Whitney $\mathrm{U}$ statistics. ${ }^{26}$ The Wilcoxon $\mathrm{W}$ is simply the smallest number of ranks, but SPSS uses an approximation to the standard normal distribution to give the $\mathrm{Z}$ statistic and the corresponding $\mathrm{p}$-value. From table 2 following results were deduced by comparing the perception of online education amidst the Covid-19 pandemic between school category and college category:

1. The data showed that there was a noticeable difference $(U=2,563.500, p=0.000)$ between the two groups regarding study materials (word/pdf file) provided by their respective academic institutions. College students scored higher (72.55) than school learners (50.55). As recently suggested by Zalat, Hamed and Bolbol, ${ }^{27}$ digital online education materials are extremely useful and allow learners to engage in various ways with their materials. Tutors and students can appreciate its importance and what is needed now and for the future by studying how these methods are empirically used in their courses to ensure that students are given the best opportunity to succeed in their classes.

\footnotetext{
${ }^{26}$ Nadim Nachar, "The Mann-Whitney U: A Test for Assessing Whether Two Independent Samples Come from the Same Distribution", Tutorials in Quantitative Methods for Psychology 4, 1 (2008): 13-20, https://doi.org/10.20982/tqmp.04.1.p013.

27 Marwa Mohamed Zalat, Mona Sami Hamed and Sarah Abdelhalim Bolbol, "The Experiences, Challenges, and Acceptance of e-Learning as a Tool for Teaching during the COVID-19 Pandemic among University Medical Staff", edited by Gwo-Jen Hwang, PLOS ONE 16, 3 (2021): e0248758, https://doi.org/10.1371/journal.pone.0248758.
} 
Kumar K. "Digital Academic Education during Covid-19 Pandemic - Perception of College and School students in Andhra Pradesh", $3-24$

Table 4: Mann-Whitney U test statistics on online education

\begin{tabular}{|c|c|c|c|c|c|c|}
\hline $\begin{array}{l}\text { S. } \\
\text { No }\end{array}$ & Advantages & $\begin{array}{l}\text { Mann- } \\
\text { Whitney U }\end{array}$ & $\begin{array}{l}\text { Wilcoxon } \\
\text { W }\end{array}$ & $\mathbf{Z}$ & $\begin{array}{l}\text { Standard } \\
\text { Error }\end{array}$ & $\begin{array}{l}\text { Asymptotic. } \\
\text { Sig (2-Sided } \\
\text { test) }\end{array}$ \\
\hline 1 & Study materials (word file/pdf, ppt) & $2,563.500$ & $4,643.500$ & -4.020 & 168.055 & .000 \\
\hline 2 & $\begin{array}{l}\text { Lectures on Television (Eg Swayam } \\
\text { Prabha) }\end{array}$ & $2,353.500$ & $4,433.500$ & -3.245 & 143.465 & .001 \\
\hline 3 & $\begin{array}{l}\text { No travel and accommodation } \\
\text { expenses }\end{array}$ & $2,023.000$ & $4,103.000$ & -1.206 & 111.960 & .228 \\
\hline 4 & Offline video lectures & $2,438.500$ & $4,518.500$ & -3.887 & 141.620 & .000 \\
\hline 5 & Self-assessment test & $2,480.000$ & $4,560.000$ & -3.629 & 163.149 & .000 \\
\hline 6 & $\begin{array}{l}\text { Improves responsibility and time- } \\
\text { management skill }\end{array}$ & $2,362.000$ & $4,442.000$ & -2.977 & 159.293 & .003 \\
\hline 7 & $\begin{array}{l}\text { Promote active and Independent } \\
\text { learning }\end{array}$ & $2,295.000$ & $4,375.000$ & -2.393 & 170.115 & .017 \\
\hline 8 & Remote learning & $1,915.000$ & $3,995.000$ & -0.512 & 52.779 & .609 \\
\hline 9 & $\begin{array}{l}\text { Over discussion board and chats, } \\
\text { questions explained promptly }\end{array}$ & $1,675.500$ & $3,755.500$ & -1.278 & 166.250 & .201 \\
\hline 10 & $\begin{array}{l}\text { Information acquisition from mobile } \\
\text { applications (such as Byjus, Vedantu, } \\
\text { Extra points, etc) }\end{array}$ & $2,772.500$ & $4,852.500$ & -5.199 & 170.115 & .000 \\
\hline 11 & Others & $2,156.500$ & $4,236.500$ & -2.220 & 120.931 & .026 \\
\hline \multicolumn{7}{|c|}{ Disadvantages } \\
\hline 1 & Faculties rush the syllabus & $2,185.000$ & $4,265.000$ & -1.959 & 151.595 & .050 \\
\hline 2 & $\begin{array}{l}\text { Non-accessibility of adequate } \\
\text { electronic devices (in homes with two } \\
\text { or more siblings) }\end{array}$ & $1,792.000$ & $3,872.000$ & -1.819 & 52.779 & .069 \\
\hline 3 & Poor internet connectivity & $2,037.500$ & $4,117.500$ & -1.042 & 143.465 & .297 \\
\hline 4 & Electricity Problem & $2,303.000$ & $4,383.000$ & -2.645 & 156.912 & .008 \\
\hline 5 & Lack of technical skills & $2,480.000$ & $4,560.000$ & -3.629 & 163.149 & .000 \\
\hline 6 & Poor video quality & $2,480.000$ & $4,560.000$ & -3.629 & 163.149 & .000 \\
\hline 7 & $\begin{array}{l}\text { Online tests are limited to multiple- } \\
\text { choice questions }\end{array}$ & $1,616.500$ & $3,696,500$ & -1.647 & 164.801 & .099 \\
\hline 8 & $\begin{array}{l}\text { Difficulty in practical-based } \\
\text { knowledge }\end{array}$ & $2,841.500$ & $4,921.500$ & -5.692 & 167.502 & .000 \\
\hline 9 & Security issues & $2,480.000$ & $4,560.000$ & -3.629 & 163.149 & .000 \\
\hline 10 & $\begin{array}{l}\text { The authenticity of the work of } \\
\text { students (teachers do not track } \\
\text { whether a student practices the work) }\end{array}$ & $2,652.000$ & $4,732.000$ & -4.509 & 169.431 & .000 \\
\hline 11 & Too much time spent on computer & $2,362.000$ & $4,442.000$ & -2.977 & 159.213 & .003 \\
\hline 12 & Others & $1,689.000$ & $3,769.000$ & -1.892 & 105.190 & 0.59 \\
\hline
\end{tabular}


2. There existed a statistically significant difference $(U=2,353.500, p=0.001)$ between two categories of respondents on lectures telecasted via Television (e.g. Swayam Prabha, Edtech), where college students (69.27) ranked higher than school scholars (54.11) did. Subsequently, Alvi and Gupta ${ }^{28}$ addressed the effects of lockdown-induced closures of schools and rural childcare centres on education and health outcomes for urban and rural poor in India, where the authors stressed that many Indian states, including Mizoram, West Bengal, and Kashmir, had regular telecast conferences as links to the Department of Human Resource Development (education). In addition, some of the most noteworthy projects launched during the pandemic are initiatives such as "KITE's Victor TV" station in the state of Kerala, "Abhiasa" in Andhra Pradesh, "Ghar Se Padhao Abhiyan" in Haryana, "ABP" Ananda, and "DD Bangla" in WEST Bengal, "Unnayan-Mera Mobile Mera Vidyalaya" in Bihar. Several state governments have also strengthened their institution ${ }^{29}$ to continue online education by using various centrally funded e-learning, for example, e-pathshala and Swayam Prabha. Balarabe ${ }^{30}$ noted that the media (including radio, television, and social media) play a significant role in providing a forum for educational programs and content, voicing the important role of mass media during the current coronavirus crisis in India.

3. There was no substantial difference $(U=2,023.000, p=0.228)$ meant for absolutely no travel and accommodation criteria for virtual learning, between the two groups, where college students (64.11) topped school students (59.71). As stated by Coman et al., 31 one of the significant advantages of computer-based learning is saving time and costs for travel.

4. There was a major difference $(U=2,438.500, p=0.000)$ between the two populations for preferring offline video lectures and again graduates (70.60) ranked higher than schoolchildren (52.67). One way to boost student interaction is using video during the lecture, rather than abandoning the live lecture, as per a study by Fatani, ${ }^{32}$ and Alpert and Hodkinson..$^{33}$ In another study by Scafuto et al., ${ }^{34}$ research on the flipped classroom, the effective use of offline video lectures and videos as part of (non-reading) in-class tasks contributes to a more positive view of teacher progress.

5. Self-assessment is important for online learning because it is one of the remote learners' most fundamental skills. ${ }^{35}$ In the present study, there was an obvious distinction ( $U=2480.000$, $\mathrm{p}=0.000$ ) between the two groups for perceiving the self-assessment test. Subsequently, Chung and Choi, ${ }^{36}$ recently published a survey that looked at the case of an English language program in South Korea to see how the abrupt shift to online language instruction has affected language instructors' teaching and evaluation practices. The study also examined the level of satisfaction of instructors and students with the changing form of English language teaching and assessment

28 Muzna Alvi and Manavi Gupta, "Learning in Times of Lockdown: How Covid-19 Is Affecting Education and Food Security in India", Food Security 12, 4 (2020): 793-796, https://doi.org/10.1007/s12571-020-01065-4.

${ }_{29}$ Nawaz, "Revisiting the Discourse on Online and Face-to-Face Classes amidst Covid-19 Lockdown: Digital Outreach, StrengthWeakness Analysis, and Constructivist View".

${ }^{30}$ Usman Bello Balarabe, Impact of COVID-19 and Pandemic Lockdown in India: Role of Media during Lockdown (India, Pune, Maharashtra: Eureka Publications, 2020), 11

31 Claudiu Coman et al., "Online Teaching and Learning in Higher Education during the Coronavirus Pandemic: Students' Perspective", Sustainability 12, 24 (2020): 10367, https://doi.org/10.3390/su122410367.

32 Tarah H. Fatani, "Student Satisfaction with Videoconferencing Teaching Quality during the COVID-19 Pandemic", BMC Medical Education 20, 1 (2020): 396, https://doi.org/10.1186/s12909-020-02310-2.

${ }_{33}$ Frank Alpert and Chris S. Hodkinson, "Video Use in Lecture Classes: Current Practices, Student Perceptions and Preferences", Education \& Training 61, 1 (2019): 31-45, https://doi.org/10.1108/ET-12-2017-0185.

34 Isabel Scafuto et al., "The Impact of Flipped Classroom in MBA Evaluation". Education \& Training 59, 9 (2017): 917-928, https:// www.learntechlib.org/p/189597/.

35 Ahmed Elzainy, Abir El Sadik and Waleed Al Abdulmonem, "Experience of E-Learning and Online Assessment during the COVID-19 Pandemic at the College of Medicine, Qassim University", Journal of Taibah University Medical Sciences 15, 6 (2020): 456-62, https:// doi.org/10.1016/j.jtumed.2020.09.005.

${ }^{36}$ Sun-Joo Chung and Lee-Jin Choi, "The Development of Sustainable Assessment during the COVID-19 Pandemic: The Case of the English Language Program in South Korea", Sustainability 13, 8 (2021): 4499, https://doi.org/10.3390/su13084499. 
Kumar K. "Digital Academic Education during Covid-19 Pandemic - Perception of College and School students in Andhra Pradesh", $3-24$

practices on the use of online learning in higher education in another analysis. Students were tremendously satisfied with new types of language evaluation techniques, but teachers were somewhat disappointed, according to the data. The findings presented language teachers with language assessment suggestions that can help them deliver more creative and long-lasting language assessment procedures that encourage self-regulated learning and long-term growth.

6. Different habits influence the time consumption of various activities and therefore are vital determinants of time management success. Time management skills take time to develop and will look different for each person. ${ }^{37}$ In the present study, there was a noticeable difference (U $=2,362.000, p=0.003$ ) between two education groups concerning an important benefit of the digital academic curriculum concerned with improving an individual's responsibility and timemanagement skills.

7. One of the most important advantages of online courses is that they allow students to learn at a time, location and speed that fits their learning style best. Digital platform learning enables learners to not only learn at their desired level, venue, and speed but also, when combined with advanced digital platforms, to provide personalized, adaptive learning. ${ }^{38}$ There was a measurable difference $(U=2,295,000, p=0.017)$ between the two populations (College -68.36 , School - 55.10) concerning the advantages of online learning in supporting active and independent learning.

8. A report on emergency education ${ }^{39}$ indicated that continuing education and learning can be a supportive factor in helping young people cope during times of disruption with stress and challenges. The role of schools during school closures in helping students and offering accessible means of learning is more important than ever. The present study findings revealed that there was no substantial difference between the two groups $(U=1,915.000, p=0.609)$ as college students (62.42) had a higher mean rank compared to school students (61.54) concerning one of the essential advantages of remote learning online education.

9. In meaningful learning and scientific inquiry, the questions of students play an important role. They are a promising source for both teaching and learning science. ${ }^{40}$ In this study, there was no substantial difference between the two groups (College -58.68 , School -65.60 ) as $U=$ $1,675.500, p=0.201$ for the variable, "Questions quickly explained through the discussion board and talks between the two populations".

10. Educational applications are social and useful for attracting students to research to increase productivity. Mobile apps offer us access to unlimited data and knowledge. These apps, in addition to impairing awareness, strengthened how colleges, universities, and various educational institutions function. It is the most coordinated way of learning and is therefore open to everyone, rich or poor. ${ }^{41}$ However, in the current study, there was a considerable difference between the two populations (College -75.82 , School - 47.01) in the procurement of information from mobile applications (e.g. Byjus, Vedantu, Extra points, etc.) in the current study (U = $2,772.500, p=0.000$ ).

\footnotetext{
${ }^{37}$ Shadnaz Asgari et al., "An Observational Study of Engineering Online Education during the COVID-19 Pandemic", edited by Mohammed Saqr, PLOS ONE 16, 4 (2021): e0250041, https://doi.org/10.1371/journal.pone.0250041.

38 Johannes König, Daniela J. Jäger-Biela and Nina Glutsch, "Adapting to Online Teaching during COVID-19 School Closure: Teacher Education and Teacher Competence Effects among Early Career Teachers in Germany", European Journal of Teacher Education 43, 4 (2020): 608-622, https://doi.org/10.1080/02619768.2020.1809650.

39 Justin Reich et al., "Remote Learning Guidance From State Education Agencies During the COVID-19 Pandemic: A First Look", preprint. EdArXiv, 2020, https://doi.org/10.35542/osf.io/437e2.

40 Petar Jandrić et al., "Teaching in the Age of Covid-19", Postdigital Science and Education 2, 3 (2020): 1069-1230, https://doi. org/10.1007/s42438-020-00169-6.

${ }^{41}$ Cedric B. Mpungose, "Emergent Transition from Face-to-Face to Online Learning in a South African University in the Context of the Coronavirus Pandemic", Humanities and Social Sciences Communications 7, 1 (2020): 113, https://doi.org/10.1057/ s41599-020-00603-x.
} 


\section{Disadvantages}

1. There was a noticeable difference $(U=2,185.000, p=0.050)$ between the two categories concerning the variable, "Faculties rush the syllabus during online classes" as the Mean Rank of college students (66.64) are larger than those of school children school (56.97).

2. Some of the major obstacles that hinder online learning are weak internet access, power supply disruption, and computer un-availabilities, such as laptops and cell phones. According to a survey conducted by Shukla, ${ }_{1}^{42}$ which was a major obstacle, the unavailability of smartphones and laptops was reported by about $27 \%$ of students. There was no important difference in the present study $(U=1,792.000, p=0.069)$ between the respondents of two educational groups for the shortage of appropriate technological devices (in homes with two or more siblings) as the p-value was greater than 0.5 .

3. Students and teachers also have difficulties accessing these online platforms, as indicated by Anviti Singh. ${ }^{43}$ Students are unable to access the internet due to financial constraints and are devoid of handheld devices, smartphones, telephones or computers, or even radio and TV. Students who have access to online classrooms encounter challenges due to a lack of physical space, which is also true for educators who are expected to deliver online classes. There are also social impediments, such as sexism against children who are forced to do home duties rather than attend early online classes. Boys are frequently obliged to labour on family farms in rural areas. The present study findings showed that there was a non-significant difference $(U$ $=2,037.500, p=0.297)$ between the two populations with limited internet connectivity, Mean Rank - School (59.47), University (64.34).

4. To get a proper signal in some rural areas, students had to travel for a few kilometres, as stated by Suparna ${ }^{44}$ so that they could attend classes or submit their tasks online. Although most Indian homes have electricity connections, the raging problem is the number of hours every day for which it is available. ${ }^{45}$ In this study, there was a substantial difference between the two populations in the electricity issue $(\mathrm{U}=2.303 .000, \mathrm{p}=.008)$. Mean Rank - College (68.48), School (54.97).

5. To be successful, online learners must possess fundamental technical abilities. These abilities take account of generating new documents, access reliable processors, connect to the internet, and download apps. Several online colleges are now offering new student orientation services. These teach students how to use the school's learning management system and other virtual resources, but they rarely address the fundamentals. ${ }^{46}$ However, in answer to the measure, "Lack of technical skills" there was a substantial difference $(U=2,480,000, p=0.000)$ between educational groups as the mean rank of college respondents (71.25) was greater when compared to school participants (51.97).

6 . The key to ensuring the quality of online education is successful support services. Online education support programs influence both tutors and learners ${ }^{47}$ Nevertheless, college students (71.25) reacted to poor video quality more than school students (51.97), becoming one of the

\footnotetext{
${ }^{42}$ Amandeep Shukla, "One of 3 Students Finds Online Classes Difficult: NCERT Survey", Hindustan Times, August 20th, 2020, https://www. hindustantimes.com/india-news/one-of-3-students-finds-online-classes-trying-ncert-survey/story-d0ZhS6OWChY2EcL1gUVNCM.html.

${ }^{43}$ A. Singh, "Online Learning and Education for Allduring and after Covid-19 Pandemic", TheFinancialExpress(blog), July 13 $3^{\text {th }}, 2020$, https:// www.financialexpress.com/education-2/online-learning-and-education-for-all-during-and-after-covid-19-pandemic/2021940/

${ }^{44}$ Roy Suparna, "Education in Lockdown: Poor Internet Connectivity Shadows Online Classes, Many Students Walking to Reception Areas", Hindustan Times, May 25th, 2020, https://www.hindustantimes.com/education/education-in-lockdown-poor-internetconnectivity-shadows-online-classes-many-students-walking-to-reception-areas/story-YixpW2WHFoyOgNxxK3GxBO.html.

${ }^{45}$ Girisha Lakshman Naik et al., "Online Teaching and Learning of Higher Education in India during COVID-19 Emergency Lockdown", Pedagogical Research 6, 1 (2021): em0090, https://doi.org/10.29333/pr/9665.

${ }^{46}$ Fernando Ferri, Patrizia Grifoni and Tiziana Guzzo, "Online Learning and Emergency Remote Teaching: Opportunities and Challenges in Emergency Situations", Societies 10, 4 (2020): 86, https://doi.org/10.3390/soc10040086.

${ }^{47}$ R. H. Huang et al., Handbook on Facilitating Flexible Learning During Educational Disruption: The Chinese Experience in Maintaining
} Undisrupted Learning in COVID-19 Outbreak (Beijing: Smart Learning Institute of Beijing Normal University, 2020). 
Kumar K. "Digital Academic Education during Covid-19 Pandemic - Perception of College and School students in Andhra Pradesh", $3-24$

interrupting problems during online learning, so there was a large gap between the two classes $(\mathrm{U}=2,480,000, \mathrm{p}=0.000)$.

7. Well-designed evaluations set clear standards that build a fair workload and provide students with opportunities for self-learning, rehearsal, practice, and feedback. Conversely, when badly planned, students can be a big impediment to thought and learning. ${ }^{48}$ In the current study, $63 \%$ of respondents denoted more than one correct answer for a single question choice, and multiple choices that bear the same choice of answer appear to be confusing. Unsurprisingly, there was no marked difference $(U=1,616.500, p=0.099)$ between the college (57.76) and school students (66.60) regarding the parameter, "Online tests are limited to objective type questions".

8 . Since the majority of lessons require practical sessions, $60 \%$ of respondents find it challenging to have hands-on experience with their core discipline. However, there was a substantial difference between the two classes $(U=2,841.500, p=0.000)$, as the mean rank of college students (76.90) was greater than that of school students (45.84).

9. According to Fernandes et al., ${ }^{49}$ digital education applications for information communication technology can cause many security risks, such as loss of confidentiality and availability, psychological stress, internet addiction, sensitive data disclosure, besides public information services theft. In the present study, there was a big variation $(U=2,480.000, p=0.000)$ in security problems between the two populations in this sample. Mean Rank - College (71.25), Mean Rank - School (51.97).

10. In both categories, there was a dramatic difference $(U=2,652.000, p=0.000)$, as the college respondents (79.94) displayed a greater mean rank for the measure, In comparison to school students (49.05), "genuineness of student work (teachers do not monitor whether the student is originally doing the task)".

11. A study by Wong et al., ${ }^{50}$ recorded that digital device usage had become inevitable amidst Covid-19 lockdown, subsequently prolonged use of smartphones lead to the increased time spent indoors and were independently associated with myopia and health-related issues. Similarly, for the variable, "Too much time spent on the system", Mean Rank - School (53.97), College (69.41), the present study showed a substantial difference $(U=2,362.000, p=0.003)$ between both levels.

$11 \%$ of respondents said that despite video conferencing bridges social links during quarantine, it poses new issues from web conference software (unwanted invasions of meeting rooms), to evolving standards for teacher work (e.g. turning on video cameras in private spaces), to new concerns regarding mandatory reporting (as teachers see within children's homes) and risks of improper teacher-student contact.

\section{Role of libraries in satisfying users need during the Pandemic}

While libraries have historically been more than the physical resources contained within their walls, this truth has been clearer than ever since the Covid-19 pandemic compelled libraries to close their doors. ${ }^{51}$ In the Covid-19 lockdown, according to Murphy et al., ${ }^{52}$ the University of Calgary pivoted to scale up online teaching, learning, and digital interaction with its community. During the first eight months of the pandemic, seven types of digital library services were

\footnotetext{
48 Kiruthika Ragupathi, Designing Effective Online Assessments (Singapore: National University of Singapore (NUS), 2020$), 15$.

${ }^{49}$ Blossom Fernandes et al., "The Impact of COVID-19 Lockdown on Internet Use and Escapism in Adolescents", Revista de Psicología Clínica con Niños y Adolescentes Vol. 7, nº. 3 (Septiembre 2020): 59-65, https://doi.org/doi: 10.21134/rpcna.2020.mon.2056.

${ }^{50}$ Chee Wai Wong et al., "Digital Screen Time During the COVID-19 Pandemic: Risk for a Further Myopia Boom?", American Journal of Ophthalmology 223 (March, 2021): 333-337, https://doi.org/10.1016/j.ajo.2020.07.034

51 Emy Nelson Decker, "Reaching Academic Library Users during the COVID-19 Pandemic: New and Adapted Approaches in Access Services", Journal of Access Services 18, 2 (2021): 77-90, https://doi.org/10.1080/15367967.2021.1900740.

52 James E. Murphy et al., "Expanding Digital Academic Library and Archive Services at the University of Calgary in Response to the COVID-19 Pandemic", IFLA Journal (August, 2021): 034003522110230, https://doi.org/10.1177/03400352211023067.
} 
created and perhaps even expanded, according to the article, with the goals of remote staff collaboration, student engagement, collections access, remote information literacy instruction, and high-quality reference services. Following that, Pooja P. Dadhe and Manju N. Dubey ${ }^{53}$ investigated the types of services provided by Indian Institutes of Technology (IITs) libraries based on the contents published on their webpages, highlighting the significant initiatives taken by the libraries that can be replicated by others to meet post-lockdown needs. In yet another study, Winata, Fadelina, and Basuki ${ }^{54}$ described numerous university library services in the new normal. To prevent mass gatherings in one area, the authors stated that the library virtual screen activities included online meetings, online discussions, virtual conferences, live streaming, and others. Furthermore, the article stated that libraries have empowered e-resources encompassing ejournals, e-books, access to journal publishers (national and international) and other supported databases to assist scholars during the lockdown. The libraries provided software and website pages accessed via a smartphone for assessing e-resources. Because traditional services were restricted due to the closure of libraries as the Covid-19 shutdown approached, statistics relating to virtual library services were analyzed and reported in Table 5 . The table clearly shows that organizing virtual events such as online book exhibitions, webinars, awareness programmes on Covid-19, and academic/research-related topics; relaxing penalty/overdue charges on borrowed library materials; and providing licenced electronic resources and educational video materials were beneficial to both the school and college populations. However, when compared to school students, online library services such as interlibrary loans, virtual research assistance, research support tools, free or extended access to e-resources, and the availability of open access resources were more favorable to college students. Sharing information via library WhatsApp group and access to print materials through scanned copies were mentioned by approximately $4 \%$ of school students (in the "others" option) as useful online library services. Subsequently, $11 \%$ of college students indicated that SOPs to control the spread of Covid-19 on the library website and Guidelines issued by competent bodies were helpful to them.

Table 5: Library online service during the pandemic

\begin{tabular}{|c|c|c|c|}
\hline S.No & Online Library Services & School & College \\
\hline 1 & Interlibrary loan service on a virtual basis & $18(14.63)$ & $31(25.20)$ \\
\hline 2 & $\begin{array}{l}\text { Virtual research assistance (Plagiarism checking, grammar correction, } \\
\text { e-mail alerts etc) }\end{array}$ & 0 & $46(37.40)$ \\
\hline 3 & Providing online research support tools & 0 & $32(26.02)$ \\
\hline 4 & $\begin{array}{l}\text { Organizing virtual events (online book exhibition, webinars, awareness } \\
\text { program on Covid-19, and academic/research related topics) }\end{array}$ & $39(31.71)$ & $57(46.34)$ \\
\hline 5 & Provide licensed E-resources / Educational Video Materials & $27(21.95)$ & $38(30.89)$ \\
\hline 6 & $\begin{array}{l}\text { Free and prolonged access to e-resources(e-books/ e-journals/ } \\
\text { e-databases) }\end{array}$ & $11(8.94)$ & $44(35.77)$ \\
\hline 7 & Relaxing penalty/overdue charges & $41(33.33)$ & $59(47.97)$ \\
\hline 8 & Availability of open access resources & $23(18.70)$ & $41(33.33)$ \\
\hline 9 & Availability of Covid-19 related information on the library website & $09(7.32)$ & $21(17.07)$ \\
\hline 10 & Others & $05(4.07)$ & $14(11.38)$ \\
\hline
\end{tabular}

\footnotetext{
53 Pooja P. Dadhe and Manju N. Dubey, "Library Services Provided During COVID-19 Pandemic: Content Analysis of Websites of Premier Technological Institutions of India", Library Philosophy and Practice (e-journal) (2020): 4445, https://digitalcommons.unl. edu/libphilprac/4445.

${ }_{54}$ Arda Putri Winata, Raisa Fadelina and Sulistyo Basuki, "New Normal and Library Services in Indonesia: A Case Study of University Libraries", Digital Library Perspectives 37, 1 (2021): 77-84, https://doi.org/10.1108/DLP-07-2020-0059.
} 
Kumar K. "Digital Academic Education during Covid-19 Pandemic - Perception of College and School students in Andhra Pradesh", $3-24$

\section{Friedman test of Overall Satisfaction Levels}

Figure 4: Friedman Test for Overall satisfaction

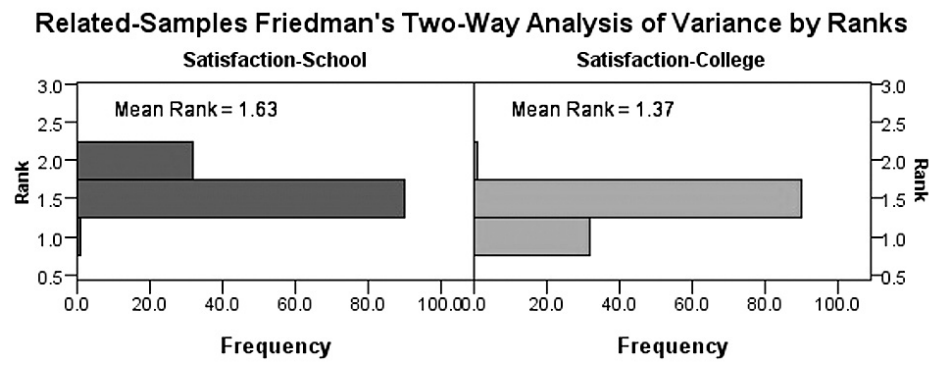

\begin{tabular}{|lr|}
\hline Total N & 123 \\
\hline Test Statistic & 29.121 \\
\hline Degrees of Freedom & 1 \\
\hline Asymptotic Sig. (2-sided test) & .000 \\
\hline
\end{tabular}

1. Multiple comparisons are not performed because there are less than three test fields.

With repeated steps, the non-parametric alternative to the one-way ANOVA is the Friedman test. It is used to monitor for differences among classes when the dependent variable being evaluated is ordinary. ${ }^{55}$ Friedman's test analysis was used to identify the overall satisfaction of the respondents with online education and the results are given in Figure 4 . The dependent variable is the 4-point Likert scale (Excellent - 1, Good - 2, Average - 3, Poor - 4) for the parameter "overall satisfaction of respondents during the Covid-19 pandemic in online education". The predictor variables are the education group (respondents from college and school). As shown in the figure, the definition of the test statistics ( $\chi 2$ ) ("Chi-square"), degrees of freedom ("df"), and degrees of freedom ("df") and level of significance ("Asymp. Sig."), the Friedman test compares the mean ranks between the different groups and demonstrates how the groups differed. The overall satisfaction of college and school students about online education in the Covid-19 freeze, $\chi^{2}(1)=29.121, \mathrm{p} \leq 0.000$, was significantly different.

\section{Findings}

For everyone in society, particularly young learners, online classes via cisco Webex meet, Google meet, Zoom, etc. are helpful as they benefit from the same learning purpose they were subsequently before the lockdown began. This is helping the teachers too as they get to interact with their students and exchange information. Students can devote some time to learning due to the sheer pace at which the online classes work, even though they are not in traditional education. Other extra-curricular events, including sport, music, motivational speaking, author discussions, and all other potential activities, are virtualized in addition to studies. Even though they

55 Shlomo S. Sawilowsky, "Nonparametric Tests of Interaction in Experimental Design", Review of Educational Research 60, 1 (1990): 91-126, https://doi.org/10.3102/00346543060001091. 
are remotely located and allow versatile communication, virtual learning is a forum for everyone to connect. ${ }^{56}$ There are several drawbacks, though, when many people get into the meeting at one time, and then in one of their houses there might be a few connexion issues, so it affects the whole meeting. For example, if everyone in the meeting needs to do something together, singing together, then the sounds are very hard to discern and the voice of someone is not heard. Moreover, as it is difficult to understand anything they say, the teacher finds it difficult to teach new lessons. ${ }^{57}$

$\mathrm{H} 1$ : In response to the Covid-19 lockdown, there is no significant difference between college and school students in overall satisfaction with the online education experience.

$\mathrm{H} 2$ : In response to the Covid-19 government shutdown, there is a wide disparity in overall satisfaction between college and school students concerning the experience of online education.

The Mann Whitney U statistics are taken into account in the present report. Here we see that for most aspects of online education, the p-value is less than 0.05 (see Table 4). Thus, we have substantial evidence to refute the null hypothesis ( $\mathrm{H} 1)$, which states that there is no substantial difference between the real-time experience of online education of college and school students during the Covid-19 pandemic. College students have a higher average rank than school students do in this situation. Rather an approximation to the $p$-value is the standard estimate used above and SPSS provides a computational procedure to construct an exact p-value. In this case, however, the sample sizes are large, so that the exact test was too software-intensive to complete, although the asymptotic $\mathrm{p}$-value should be sufficiently precise. Therefore, $\mathrm{H} 2$, which notes that the real-time experience of online education during the Covid-19 pandemic between college and school students is considerably different, is accepted.

H3: In response to the Covid-19 suspension, there is no significant disparity between college and school learners in overall satisfaction with the general experience of online education.

$\mathrm{H} 4$ : There is a significant difference in overall satisfaction between college and school students with general online education experience in response to the Covid-19 shutdown.

Friedman test revealed that there was a statistically significant difference between two categories of online learners amidst Covid $-19, X^{2}(1)=29.121, p=0.000$. Hence, the null hypothesis (H3) is rejected while the alternative $\mathrm{H} 4$ hypothesis is accepted.

\section{Conclusion}

During the Covid-19 pandemic, there was a substantial difference in perceptions of online learning between college and schoolchildren, according to the current study. When discussing the advantages of virtual schooling, there was a clear distinction between the two groups. Offline video lectures, study materials (word file/pdf, ppt), and self-assessment assessments, in which college students scored higher than schoolchildren on satisfaction. For the factors remote learning, no travel or lodging costs, and Questions swiftly answered on the discussion board and in chats, there was no significant difference between the survey respondents. When it came to the disadvantages, there was a significant difference in the opinions of study participants on variables such as lack of technical skills, poor video quality, and difficulty in practical-based knowledge, while both groups were both annoyed by poor internet connectivity, lack of access to

\footnotetext{
${ }^{56}$ Giorgi Basilaia and David Kvavadze, "Transition to Online Education in Schools during a SARS-CoV-2 Coronavirus (COVID-19) Pandemic in Georgia", Pedagogical Research 5, 4 (2020). https://doi.org/10.29333/pr/7937.

57 Abdulsalam Almanthari Mailizar, Suci Maulina and Sandra Bruce, "Secondary School Mathematics Teachers' Views on E-Learning Implementation Barriers during the COVID-19 Pandemic: The Case of Indonesia", Eurasia Journal of Mathematics, Science and Technology Education 16, 7 (2020): em1860. https://doi.org/10.29333/ejmste/8240.
} 
Kumar K. "Digital Academic Education during Covid-19 Pandemic - Perception of College and School students in Andhra Pradesh", $3-24$

adequate electronic devices (in homes with two or more siblings), and online tests. As a result, there was a considerable variation in the overall experience of online education between school and college students throughout the epidemic, which was unsurprising. During the Covid-19 lockdown, students' lives are framed by a predetermined regimen that includes school, homework, coaching or tuition courses, co-curricular events, and more. In positions of accessibility, identity-pacing, richer content, and objective-based information, among other things, online learning provides potential advantages over traditional classroom learning. However, there are certain drawbacks to using the internet to learn. Experts remind out that to complete their job and studies on time, students must exercise significant self-discipline. Lack of social contact or personal ties with classmates, students, and teachers can also affect personality development. Students will need good time management skills if there is more flexibility than they can handle, or they will fall far behind. Some argue that when students study online, they have a higher burden but less practical experience. The breadth and scope of online education are expanding far beyond what anyone could have imagined. It will be easier to be better equipped to tackle the task of working and accepting the new possibilities in this current paradigm if you evaluate both the benefits and drawbacks of online learning.

\section{Limitations}

This study does not cover all elements influencing students' perceptions of online education at their institutions, it focuses on only a few: demographic characteristics, benefits, and drawbacks of online education suffered by students during the Covid-19 disaster.

Due to time constraints, this course is only open to students from the Andhra Pradesh state. This study employs a random sample of learners that are currently enrolled in a virtual learning platform. From July to September 2020, this research was carried out.

\section{References:}

4. Abbasi, Sahar, Tahera Ayoob, Abdul Malik and Shabnam Iqbal Memon. "Perceptions of Students Regarding E-Learning during Covid-19 at a Private Medical College". Pakistan Journal of Medical Sciences 36 (COVID19-S4) (2020). https://doi.org/10.12669/pjms.36.COVID19-S4.2766.

5. Alpert, Frank and Chris S. Hodkinson. "Video Use in Lecture Classes: Current Practices, Student Perceptions and Preferences". Education \& Training 61, 1 (2019): 31-45. https://doi.org/10.1108/ ET-12-2017-0185.

6. Alvi, Muzna and Manavi Gupta. "Learning in Times of Lockdown: How Covid-19 Is Affecting Education and Food Security in India". Food Security 12, 4 (2020): 793-796. https://doi.org/10.1007/ s12571-020-01065-4.

7. Amita. E-Learning Experience of Students in Higher Education Institutions During the COVID-19 Pandemic: A Primary Survey. COVID-19 Pandemic: A Global Challenge. New Delhi: Raj Pal Singh, Anupama Singh and Rakesh Kumar; COVID-19 Pandemic: A Global Challenge, Aryan Publications, 2020.

8. "AP Government Uses Online Platforms Educate Students during Covid-19 Lockdown - Education Today News". India Today, May $11^{\text {th }}$, 2020. https://www.indiatoday.in/education-today/news/story/apgoverment-uses-online-platfroms-educate-students-during-covid-19-lockdown-1676707-2020-05-11.

9. Asgari, Shadnaz, Jelena Trajkovic, Mehran Rahmani, Wenlu Zhang, Roger C. Lo and Antonella Sciortino. "An Observational Study of Engineering Online Education during the COVID-19 Pandemic". Edited by Mohammed Saqr. PLOS ONE 16, 4 (2021): e0250041. https://doi.org/10.1371/journal. pone.0250041.

10. Balarabe, Usman Bello. Impact of COVID-19 and Pandemic Lockdown in India: Role of Media during Lockdown. India, Pune, Maharashtra: Eureka Publications, 2020. 
Kumar K. "Digital Academic Education during Covid-19 Pandemic - Perception of College and School students in Andhra Pradesh",

11. Basilaia, Giorgi and David Kvavadze. "Transition to Online Education in Schools during a SARSCoV-2 Coronavirus (COVID-19) Pandemic in Georgia". Pedagogical Research 5, 4 (2020). https://doi. org/10.29333/pr/7937.

12. Bozkurt, Aras, Insung Jung, Junhong Xiao, Viviane Vladimirschi, Robert Schuwer, Gennady Egorov, Sarah R Lambert et al. "A Global Outlook to the Interruption of Education Due to COVID-19 Pandemic: Navigating in a Time of Uncertainty and Crisis". Asian Journal of Distance Education 15, 1 (2020): 1-126.

13. Chung, Sun-Joo and Lee-Jin Choi. "The Development of Sustainable Assessment during the COVID-19 Pandemic: The Case of the English Language Program in South Korea". Sustainability 13, 8 (2021): 4499. https://doi.org/10.3390/su13084499.

14. Coman, Claudiu, Laurențiu Gabriel Țîru, Luiza Meseșan-Schmitz, Carmen Stanciu and Maria Cristina Bularca. "Online Teaching and Learning in Higher Education during the Coronavirus Pandemic: Students' Perspective". Sustainability 12, 24 (2020): 10367. https://doi.org/10.3390/ su122410367.

15. Dadhe, Pooja P. and Manju N. Dubey. "Library Services Provided During COVID-19 Pandemic: Content Analysis of Websites of Premier Technological Institutions of India". Library Philosophy and Practice (e-journal) (2020): 4445. https://digitalcommons.unl.edu/libphilprac/4445.

16. De', Rahul, Neena Pandey and Abhipsa Pal. "Impact of Digital Surge during Covid-19 Pandemic: A Viewpoint on Research and Practice". International Journal of Information Management 55 (December 2020): 102171. https://doi.org/10.1016/j.ijinfomgt.2020.102171.

17. Decker, Emy Nelson. "Reaching Academic Library Users during the COVID-19 Pandemic: New and Adapted Approaches in Access Services". Journal of Access Services 18, 2 (2021): 77-90. https://doi.org/ 10.1080/15367967.2021.1900740.

18. Department of School Education \& Literacy, Ministry of Human Resource Development, and Government of India. "India Report Digital Education." New Delhi, 2020. file:///C:/Users/Nanchari/ Desktop/CAEO\%20Reviewer/India_Report_Digital_Education_0.pdf.

19. Devi, G. Padmini and Sirisha Deepthi Sornapudi. "An Insight into Digital Education in India during COVID-19 from the Lens of Students". Current Journal of Applied Science and Technology (November2020): 83-94. https://doi.org/10.9734/cjast/2020/v39i3531057.

20. Dhawan, Shivangi. "Online Learning: A Panacea in the Time of COVID-19 Crisis". Journal of Educational Technology Systems 49, 1 (2020): 5-22. https://doi.org/10.1177/0047239520934018.

21. Elzainy, Ahmed, Abir El Sadik and Waleed Al Abdulmonem. "Experience of E-Learning and Online Assessment during the COVID-19 Pandemic at the College of Medicine, Qassim University". Journal of Taibah University Medical Sciences 15, 6 (2020): 456-62. https://doi.org/10.1016/j. jtumed.2020.09.005.

22. Fatani, Tarah H. "Student Satisfaction with Videoconferencing Teaching Quality during the COVID-19 Pandemic". BMC Medical Education 20, 1 (2020): 396. https://doi.org/10.1186/s12909-020-02310-2.

23. Fernandes, Blossom, Urmi Nanda Biswas, Roseann Tan-Mansukhani, Alma Vallejo and Cecilia A Essau. "The Impact of COVID-19 Lockdown on Internet Use and Escapism in Adolescents". Revista de Psicología Clínica con Niños y Adolescentes Vol. 7, nº 3 (Septiembre 2020): 59-65. https://doi.org/doi: 10.21134/rpcna.2020.mon.2056.

24. Ferri, Fernando, Patrizia Grifoni and Tiziana Guzzo. "Online Learning and Emergency Remote Teaching: Opportunities and Challenges in Emergency Situations". Societies 10, 4 (2020): 86. https:// doi.org/10.3390/soc10040086.

25. Huang, R. H., D. J. Liu, A. Tlili, J. F. Yang and H. H. Wang. Handbook on Facilitating Flexible Learning During Educational Disruption: The Chinese Experience in Maintaining Undisrupted Learning in COVID-19 Outbreak. Beijing: Smart Learning Institute of Beijing Normal University, 2020.

26. Jandrić, Petar, David Hayes, Ian Truelove, Paul Levinson, Peter Mayo, Thomas Ryberg, Lilia D. Monzó et al. "Teaching in the Age of Covid-19". Postdigital Science and Education 2, 3 (2020): 1069-1230. https://doi.org/10.1007/s42438-020-00169-6. 
Kumar K. "Digital Academic Education during Covid-19 Pandemic - Perception of College and School students in Andhra Pradesh", $3-24$

27. Khalil, Rehana, Ali E. Mansour, Walaa A. Fadda, Khaled Almisnid, Mohammed Aldamegh, Abdullah Al-Nafeesah, Azzam Alkhalifah and Osama Al-Wutayd. "The Sudden Transition to Synchronized Online Learning during the COVID-19 Pandemic in Saudi Arabia: A Qualitative Study Exploring Medical Students' Perspectives". BMC Medical Education 20, (2020). https://doi.org/10.1186/s12909-020-02208-z.

28. König, Johannes, Daniela J. Jäger-Biela and Nina Glutsch. "Adapting to Online Teaching during COVID-19 School Closure: Teacher Education and Teacher Competence Effects among Early Career Teachers in Germany". European Journal of Teacher Education 43, 4 (2020): 608-622. https://doi.org/10.1 080/02619768.2020.1809650.

29. Lakshman Naik, Girisha, Malteshkumar Deshpande, D. C. Shivananda, C. P. Ajey and G. C. Manjunath Patel. "Online Teaching and Learning of Higher Education in India during COVID-19 Emergency Lockdown". Pedagogical Research 6, 1 (2021): em0090. https://doi.org/10.29333/pr/9665.

30. Mailizar, Abdulsalam Almanthari, Suci Maulina and Sandra Bruce. "Secondary School Mathematics Teachers' Views on E-Learning Implementation Barriers during the COVID-19 Pandemic: The Case of Indonesia". Eurasia Journal of Mathematics, Science and Technology Education 16, 7 (2020): em1860. https://doi.org/10.29333/ejmste/8240.

31. Mardon, Austin, Catherine Mardon and Jiahui Mardon Luo. Education During COVID-19. S. I.: Golden Meteorite Press, 2020.

32. Mhlanga, David and Tankiso Moloi. "COVID-19 and the Digital Transformation of Education: What Are We Learning on 4IR in South Africa?" Education Sciences 10, 7 (2020): 180. https://doi. org/10.3390/educsci10070180.

33. Milenović, Živorad. "Application of Mann-Whitney U Test in Research of Professional Training of Primary School Teachers". Metodički Obzori / Methodological Horizons 6, 1 (2011): 73-79. https://doi. org/10.32728/mo.06.1.2011.06.

34. Mpungose, Cedric B. "Emergent Transition from Face-to-Face to Online Learning in a South African University in the Context of the Coronavirus Pandemic". Humanities and Social Sciences Communications 7, 1 (2020): 113. https://doi.org/10.1057/s41599-020-00603-x.

35. Mukhtar, Khadijah, Kainat Javed, Mahwish Arooj and Ahsan Sethi. "Advantages, Limitations and Recommendations for Online Learning during COVID-19 Pandemic Era." Pakistan Journal of Medical Sciences 36 (COVID19-S4) (2020). https://doi.org/10.12669/pjms.36.COVID19-S4.2785.

36. Murphy, James E., Carla J. Lewis, Christena A. McKillop and Marc Stoeckle. “Expanding Digital Academic Library and Archive Services at the University of Calgary in Response to the COVID-19 Pandemic". IFLA Journal (August, 2021): 034003522110230. https://doi. org/10.1177/03400352211023067.

37. Muthuprasad, T., S. Aiswarya, K. S. Aditya and Girish K. Jha. "Students' Perception and Preference for Online Education in India during COVID -19 Pandemic". Social Sciences \& Humanities Open 3, 1 (2021): 100101. https://doi.org/10.1016/j.ssaho.2020.100101.

38. Nachar, Nadim. "The Mann-Whitney U: A Test for Assessing Whether Two Independent Samples Come from the Same Distribution". Tutorials in Quantitative Methods for Psychology 4, 1 (2008): 13-20. https:// doi.org/10.20982/tqmp.04.1.p013.

39. Nawaz, Sarif. "Revisiting the Discourse on Online and Face-to-Face Classes amidst Covid-19 Lockdown: Digital Outreach, Strength-Weakness Analysis, and Constructivist View". South Asia Journal (blog). June $7^{\text {th }}, 2020$. http://southasiajournal.net/revisiting-the-discourse-on-online-and-face-to-face-classesamidst-covid-19-lockdown-digital-outreach-strength-weakness-analysis-and-constructivist-view/.

40. OECD. Education Responses to COVID-19: Embracing Digital Learning and Online Collaboration. March 2020. https://read.oecd-ilibrary.org/view/?ref=120_120544-8ksud7oaj2\&title=Education_ responses_to_Covid-19_Embracing_digital_learning_and_online_collaboration\&_ $\mathrm{ga}=2.196555183 .2030078247 .1626438563-540793052.1625722470$.

41. OECD. "Learning Remotely When Schools Close: How Well Are Students and Schools Prepared? Insights from PISA". OECD Policy Responses to Coronavirus (COVID-19), 2020. https://doi. org/10.1787/3bfda1f7-en. 
42. Onyema, Edeh Michael, Nwafor Chika Eucheria, Faith Ayobamidele Obafemi, Shuvro Sen, Fyneface Grace Atonye, Aabha Sharma and Alhuseen Omar Alsayed. "Impact of Coronavirus Pandemic on Education". Journal of Education and Practice (May 2020). https://doi.org/10.7176/JEP/11-13-12.

43. Peat, Jennifer K., Craig Mellis, Katrina Williams and Wei Xuan. Health Science Research: A Handbook of Quantitative Methods. 2020. https://www.taylorfrancis.com/books/9781003115922.

44. Radha, R., K. Mahalakshmi, V. Sathish Kumar, and A. R. Saravanakumar. "E-Learning during Lockdown of Covid-19 Pandemic: A Global Perspective". International Journal of Control and Automation 13, 4 (2020): 1088-1099.

45. Ragupathi, Kiruthika. Designing Effective Online Assessments. Singapore: National University of Singapore (NUS), 2020.

46. Rajab, Mohammad H., Abdalla M. Gazal and Khaled Alkattan. "Challenges to Online Medical Education During the COVID-19 Pandemic". Cureus, July 2020. https://doi.org/10.7759/cureus.8966.

47. Reich, Justin, Christopher J. Buttimer, Alison Fang, Garron Hillaire, Kelley Hirsch, Laura R. Larke, Joshua Littenberg-Tobias et al. "Remote Learning Guidance From State Education Agencies During the COVID-19 Pandemic: A First Look". Preprint. EdArXiv, 2020. https://doi.org/10.35542/osf. io/437e2.

48. Rochon, Justine, Matthias Gondan and Meinhard Kieser. "To Test or Not to Test: Preliminary Assessment of Normality When Comparing Two Independent Samples". BMC Medical Research Methodology 12, 1 (2012). https://doi.org/10.1186/1471-2288-12-81.

49. Sawilowsky, Shlomo S. "Nonparametric Tests of Interaction in Experimental Design". Review of Educational Research 60, 1 (1990): 91-126. https://doi.org/10.3102/00346543060001091.

50. Scafuto, Isabel, Fernando Serra, Eduardo Mangini, Emerson Antonio Maccari and Roberto Ruas. "The Impact of Flipped Classroom in MBA Evaluation". Education \& Training 59, 9 (2017): 917-928. https:// www.learntechlib.org/p/189597/.

51. Shenoy, Veena, Sheetal Mahendra, and Navita Vijay. "COVID 19-Lockdown: Technology Adaption, Teaching, Learning, Students Engagement and Faculty Experience". Mukt Shabd Journal IX, IV (2020): 698-702.

52. Shukla, Amandeep. "One of 3 Students Finds Online Classes Difficult: NCERT Survey". Hindustan Times, August 20th, 2020 . https://www.hindustantimes.com/india-news/one-of-3-students-findsonline-classes-trying-ncert-survey/story-d0ZhS6OWChY2EcL1gUVNCM.html.

53. Singh, Anviti. "Online Learning and Education for All during and after Covid-19 Pandemic". The Financial Express (blog). July 13 ${ }^{\text {th }}, 2020$. https://www.financialexpress.com/education-2/ online-learning-and-education-for-all-during-and-after-covid-19-pandemic/2021940/.

54. Stephanie. "Mann Whitney U Test: Definition, How to Run". Statistics How To. April 25 $5^{\text {th }}$, 2021. https:// www.statisticshowto.com/mann-whitney-u-test/.

55. Suparna, Roy. "Education in Lockdown: Poor Internet Connectivity Shadows Online Classes, Many Students Walking to Reception Areas". Hindustan Times, May 25 $5^{\text {th }}, 2020$. https://www.hindustantimes. com/education/education-in-lockdown-poor-internet-connectivity-shadows-online-classes-manystudents-walking-to-reception-areas/story-YixpW2WHFoyOgNxxK3GxBO.html.

56. Tripathy, Sasikanta and Suman Devarapalli. "Emerging Trend Set by a Start-ups on Indian Online Education System: A Case of Byju's". Journal of Public Affairs 21, 1 (2021). https://doi.org/10.1002/ pa.2128.

57. UNESCO. Education: From Disruption to Recovery. March $4^{\text {th }}, 2020$.Accessed August $24^{\text {th }}, 2021$. https:// en.unesco.org/covid19/educationresponse.

58. Winata, Arda Putri, Raisa Fadelina and Sulistyo Basuki. "New Normal and Library Services in Indonesia: A Case Study of University Libraries". Digital Library Perspectives 37, 1 (2021): 77-84. https://doi.org/10.1108/DLP-07-2020-0059.

59. Wiranota, H., and T. T. Wijaya. "The International Students' Perception towards Online Learning Using the Tencent Meeting during Covid-19 Outbreak". Journal of Physics: Conference Series 1823, 1 (2021): 012011. https://doi.org/10.1088/1742-6596/1823/1/012011. 
Kumar K. "Digital Academic Education during Covid-19 Pandemic - Perception of College and School students in Andhra Pradesh", $3-24$

60. Wong, Chee Wai, Andrew Tsai, Jost B. Jonas, Kyoko Ohno-Matsui, James Chen, Marcus Ang and Daniel Shu Wei Ting. "Digital Screen Time During the COVID-19 Pandemic: Risk for a Further Myopia Boom?". American Journal of Ophthalmology 223 (March, 2021): 333-337. https://doi.org/10.1016/j. ajo.2020.07.034.

61. Xu, Yanbin, and Zhekai Wu. "An Investigation of Obstacles of Current Online Classes Encountered by Students from an International Department of a Senior High School in Hangzhou during the 2019-NCov Period". In Proceedings of the 2020 3rd International Conference on Humanities Education and Social Sciences (ICHESS 2020). Chengdu, China: Atlantis Press, 2020. https://doi.org/10.2991/ assehr.k.201214.486.

62. Zalat, Marwa Mohamed, Mona Sami Hamed and Sarah Abdelhalim Bolbol. "The Experiences, Challenges, and Acceptance of e-Learning as a Tool for Teaching during the COVID-19 Pandemic among University Medical Staff". Edited by Gwo-Jen Hwang. PLOS ONE 16, 3 (2021): e0248758. https://doi.org/10.1371/journal.pone.0248758.

\title{
Дигитално академско образовање током пандемије Covid-19 - перцепција студената и ученика у Андра Прадешу
}

\begin{abstract}
Сажетак
Циљ ове студије био је да се испита став студената и ученика Андра Прадеша према виртуелном образовању коришћењем алата за веб-конференције, као одговору на кризу изазвану пандемијом Covid-19. У периоду од јула до септембра 2020. године спроведена је онлајн анкета, чија су 123 одговора одабрана за студију. Да би се одговорило на циљеве истраживања, подаци су испитани коришћењем Ман-Витнијевог У теста и Фридмановог теста. Од 123 особе које су учествовале у онлајн анкети, 48\% су биле средњошколци, а 52\% студенти. Мушкарци су чинили 63\% испитаника, а жене 37\%. Највише ученика (30\%) било је узраста од 12 до 15 година, док је већина студената (39\%) имала од 20 до 23 године. Када је у питању приступ апликацијама за веб-конференције, најпопуларније изборе међу учесницима анкете представљали су мобилни телефони и таблети. Најчешће коришћени алати за виртуелно учење путем веб конференција били су Zoom (90\%) и Cisco Webex Meeting (87\%). Резултати Ман-Витнијевог У теста су открили да су студенти постигли боље резултате од школараца, што указује на то да су они боље одреаговали на одређене аспекте онлајн образовања у односу на ученике. Тест је открио статистички значајно одступање између очекивања студената и ученика у вези са предностима и недостацима онлајн учења. Штавише, Фридманов тест је открио да се степен свеукупног задовољства значајно разликује код студената и ученика ( $\chi 2$ (1) = 29,121, $п \leq 0,000)$. Поред тога, и школска и студентска популација имале су користи од онлајн библиотечких услуга као што су виртуелне изложбе књига, вебинари и програми подизања свести о пандемији Covid-19 и темама које се односе на академски/истраживачки рад, као и од смањења казни/ заосталих накнада за позајмљену библиотечку грађу и обезбеђивања лиценцираних електронских извора и едукативних видео-материјала.
\end{abstract}

Кључне речи: онлајн образовање, Covid-19 закључавање, алати за веб-конференције, школа, студенти, У-тест, онлајн библиотечке услуге 